\title{
EFFECT OF pH, PHOSPHATE AND/OR MALATE ON SULFATE SORPTION ON ANDISOLS
}

\author{
Massimo Pigna, ${ }^{1}$ Alejandra A. Jara ${ }^{2}$, María de la Luz Mora ${ }^{2}$ \\ and Antonio Violante ${ }^{1}$
}

${ }^{1}$ Dipartimento di Scienze del Suolo, della Pianta e dell'Ambiente, Università di Napoli

Federico II, Napoli, Italy. Correspondence: violante@unina.it

${ }^{2}$ Departamento de Ciencias Químicas, Universidad de La Frontera, Casilla

54-D, Temuco, Chile

\section{Efecto del pH, fosfato y/o malato sobre la adsorción de sulfato en Andisoles}

Key words: Sulfate, adsorption, Andisol, mineralogical composition, phosphate, malate.

\begin{abstract}
The sulfate sorption was studied on Andisols with variable mineralogical composition and low organic matter content in presence and absence of phosphate or malate ligands at different $\mathrm{pH}$. Crystalline clay mineralogy was similar for all the studied samples, except for the $2 \mathrm{C}$ horizon of the pedon 2, which did not show crystalline minerals. The soil samples showed content of allophane ranging from $16 \%$ to $42 \%$. The sulfate adsorption decreased when descending the first 3 horizons (A1, 2A 2 and $3 \mathrm{Bw} 1)$ of the pedon 1 . This behavior was attributed to the decreasing organic carbon content. At different $\mathrm{pH}$ sulfate sorption was drastically decreased by increasing the $\mathrm{pH}$ from 4.0 to 7.0 , precisely by $80 \%$ for sample 5 to $100 \%$ for sample 1. Experiments on the competitive sorption of phosphate and sulfate on volcanic soils were carried out. Sulfate sorption was reduced even in the presence of low concentrations of phosphate ions (phosphate/sulfate molar ratio $<<1$ ). Sulfate sorption was influenced by many factors as the organic carbon content, $\mathrm{pH}$, the mineralogical composition of soil samples and the order of sulfate and phosphate addition into the soils. Sulfate competes with phosphate particularly when added before phosphate and at low $\mathrm{pH}$ values $(\mathrm{pH}<4.5)$. Phosphate more than malate affected the kinetics of sulfate sorption onto a volcanic soil containing a large amount of allophanic materials.
\end{abstract}

Palabras claves: Sulfato, adsorción, Andisol, composición mineralógica, fosfato, malate 


\section{RESUMEN}

La adsorción de sulfato fue estudiada en Andisoles con una composición mineralógica variable y bajo contenido de materia orgánica en presencia y ausencia de fosfato o malato a diferentes $\mathrm{pH}$. La mineralogía de las arcillas cristalinas fue similar para todos las muestras estudiadas, excepto para el horizonte $2 \mathrm{C}$ del pedon 2 , la cual no mostró minerales cristalinos. Las muestras de suelo presentaron contenidos de alofán en el rango de 16 a $42 \%$. La adsorción de sulfato incrementó al descender los primeros 3 horizontes (A1, 2A2 and 3Bw1) del pedon 1. Este comportamiento fue atribuído a la disminución del contenido de carbono orgánico. A diferentes $\mathrm{pH}$ la adsorción de sulfato fue drásticamente disminuída el aumento del $\mathrm{pH}$ desde 4,0 a 7,0, desde un $80 \%$ para la muestra 5 a $100 \%$ para la muestra 1. La adsorción de sulfato fue reducida incluso en presencia de bajas concentraciones de iones fosfato (razón molar fosfato/sulfato 1). Experimentos de adsorción competitiva de fosfato y sulfatos fueron realizado en suelos volcánicos. La adsorción de sulfato fue influenciada por muchos factores, como el contenido de materia orgánica, $\mathrm{pH}$, composición mineralógica de los suelos y el orden de adición de sulfato y fosfato en los suelos. Sulfato compite con fosfato particularmente cuando es adicionado antes que fosfato y a bajos valores de $\mathrm{pH}(\mathrm{pH}$ 4,4). Fosfato más que malato afectó la cinética de la adsorción de sulfato en un suelo volcánico conteniendo una gran cantidad de materiales alofánicos.

\section{INTRODUCTION}

Volcanic ash soils (Andisols) may adsorb high amounts of phosphate and sulfate for the presence of short-range ordered variable charge minerals (allophane, imogolite, $\mathrm{Al}$ and $\mathrm{Fe}$ oxides) characterized by high surface area and reactivity (Parfitt, 1990; Huang and Violante, 1986; Mora and Canales, 1995; Vacca et al., 2003). Gunjigake and Wada (1980) indicated that the more reactive forms of aluminium in fixing phosphate anions in Andisols are the following: i) allophane and imogolite; ii) allophane-like components; iii) aluminium associated with humic substances and iv) aluminium present in the interlayers of expandable phyllosilicates.

Phosphate ions should be able to form very strong inner-sphere complexes, whereas sulfate may form only outersphere complexes on variable charge minerals (Parfitt, 1990; Zhang and Sparks, 1990). However, there is some evidence by X-ray absorption fine-structure (XAFS) that sulfate can also be adsorbed as an inner-sphere complex. Turner and Kramer (1991) and Sparks (1999) demonstrated that sulfate may be adsorbed on variable charge minerals forming at all, $\mathrm{pH}$ values, both inner-sphere and outer-sphere $\mathrm{SO}_{4}$ sorption complexes with the former becoming more dominant with decreasing $\mathrm{pH}$ and increasing sulfate concentrations. Peak et al. (2001) demonstrated that sulfate forms inner-sphere monodentate surface complexes on hematite, but on goethite it forms only outer-sphere surface complexes at $\mathrm{pH} \quad 6.0$ and a mixture of outer-sphere and inner-sphere surface complexes below $\mathrm{pH}$ 6.0. According to these authors sulfate forms outer-sphere surface complexes on ferrihydrite.

Violante et al. (1996) and Liu et al. (1999) demonstrated that sulfate adsorbed on the external surfaces of variable charge minerals may be easily replaced by phosphate, whereas sulfate present in the network of metal oxides (e.g. Al-hydroxy sulfate precipitates) cannot be completely removed. Organic substances play a very important role on phosphate and sulfate sorption on soil components (Violante et al., 1996; Jara at al., 2006), but studies on the competitive sorption of these anions on soil samples characterized by differences in chemical and mineralogical properties have received scant attention. Recently, Mora et al. (2005) studied the effect of organic matter content 
and soil chemical properties on sulfate sorption in Chilean Andisols. The increasing of organic matter decreased the sulfate adsorption.

The aim of the present work was to study the factors that influence the sulfate sorption, as $\mathrm{pH}$, mineralogical properties, organic carbon content and presence of phosphate or malate on Italian Andisols.

\section{MATERIALS AND METHODS}

Five soils (Andisols) derived from volcanic materials present in the caldera of Roccamonfina volcano (Central-Southern Italy) were selected. The samples 1-4 were collected from the horizons A1, 2A2, 3Bw1 and $4 \mathrm{Bw} 2$ of an Eutric Fulvudand (Pedon 1), sample 5 was collected from a $2 \mathrm{C}$ horizon of an Eutric Pachic Fulvudand (Pedon 2) (Vacca et al., 2003). Bulk samples were air-dried and crushed to pass a 2-mm sieve. All analyses were performed on air-dried $<2$-mm soil according to the procedures published by Ministry for Agricoltural and Forestry Policy (2000). Soil pH was measured by potentiometry in soil: solution suspensions of 1:2.5 $\mathrm{H}_{2} \mathrm{O}$, and 1:50 $1 \mathrm{M}$ $\mathrm{NaF}$. Organic $\mathrm{C}$ was estimated by wet digestion with a Walkley-Black procedure. The allophane content was estimated from selective dissolution extracts (Parfitt, 1990) (Table 1). The chemical and mineralogical properties were described in a previous work (Vacca et al., 2003).

Table 1: Chemical and mineralogical properties of soil samples.

Cuadro 1: Propiedades químicas y mineralógicas de las muestras de suelo.

\begin{tabular}{|l|c|c|c|c|c|}
\hline $\begin{array}{l}\text { Samples } \\
\text { Horizons }\end{array}$ & $\mathrm{pH} \mathrm{H}_{2} \mathrm{O}$ & $\mathrm{pH} \mathrm{NaF}$ & $\begin{array}{r}\text { Organic } \\
\text { Carbon } \\
\left(\mathrm{g} \mathrm{kg}^{-1}\right)\end{array}$ & $\begin{array}{c}\text { Allophane } \\
(\%)\end{array}$ & $\begin{array}{c}\text { Mineralogy (c) } \\
(<0.002 \mathrm{~mm})\end{array}$ \\
\hline 1) $\mathrm{A} 1$ (a) & 6,7 & 10,9 & 184 & 17 & $\mathrm{P} 1, \mathrm{M}, \mathrm{Ht}, \mathrm{Ch}$, or Vt, HIV \\
2) 2A2 (a) & 6,7 & 11,3 & 74 & 16 & $\mathrm{P} 1, \mathrm{M}, \mathrm{Ht}, \mathrm{Ch}$, or Vt, HIV \\
3) 3Bw1 (a) & 6,4 & 11,3 & 37 & 27 & $\mathrm{P} 1, \mathrm{M}, \mathrm{Ht}, \mathrm{Ch}$, or Vt, HIV \\
4) 4Bw 2 (a) & 6,1 & 11,2 & 12 & 23 & $\mathrm{P} 1, \mathrm{M}, \mathrm{Ht}, \mathrm{HHt}, \mathrm{Ch}$, or Vt, HIV \\
5) 2C (b) & 5,5 & 11,0 & 2 & 42 & - \\
\hline
\end{tabular}

(a) Horizons of Pedon 1 (Vacca et al., 2003)

(b) Horizon of Pedon 2 (Vacca et al., 2003)

(c) Abbreviations: $\mathrm{Ch}=$ chlorite; $\mathrm{HHt}=$ hydrated halloysite; HIV = hydroxy

interlayered vermiculite, $\mathrm{Ht}$, = halloysite; $\mathrm{M}=$ mica; $\mathrm{Pl}=$ plagioclase; $\mathrm{Vt}=$ vermiculite . 


\section{Phosphate and sulfate sorption isotherms}

Three hundred mg of soil samples were equilibrated with $\mathrm{KCl} 0.02 \mathrm{M}$ at $\mathrm{pH}$ 4.5. Suitable amounts of $0.1 \mathrm{~mol} \mathrm{~L}^{-1}$ solutions containing sulfate or phosphate were then added in order to have an initial sulfate or phosphate concentration in the range $5 \mathrm{x}$ $10^{-4}$ to $10^{-2} \mathrm{~mol} \mathrm{~L}{ }^{-1}$. The $\mathrm{pH}$ of each suspension was kept at the initial value by adding 0.1 or $0.01 \mathrm{~mol} \mathrm{~L}^{-1} \mathrm{HCl}$ or $\mathrm{NaOH}$. The suspensions were shaken for $24 \mathrm{~h}$. The final suspensions $(20 \mathrm{~mL})$ were centrifuged at $10,000 \mathrm{~g}$ for $20 \mathrm{~min}$. and filtered through a $0.22-\mu \mathrm{m}$ membrane filter.

\section{Sorption of sulfate as a function of $\mathrm{pH}$}

Suitable amounts of sulfate $0.1 \mathrm{~mol} \mathrm{~L}^{-1}$ were added to $300 \mathrm{mg}$ of each soil sample in reaction flasks at three different $\mathrm{pH}$ values $(3.5,4.5,5.5)$. The $\mathrm{pH}$ of each suspensions was kept at the initial value by adding 0.1 or $0.01 \mathrm{~mol} \mathrm{~L}^{-1} \mathrm{KCl}$ or $\mathrm{NaOH}$. The suspensions were shaken for $24 \mathrm{~h}$. The final suspensions $(20 \mathrm{~mL})$ were centrifuged at $10,000 \mathrm{~g}$ for $20 \mathrm{~min}$. and filtered through a $0.22-\mu \mathrm{m}$ membrane filter.

\section{Competitive sorption of phosphate and sulphate}

Competitive sorption of phosphate and sulfate, added as a mixture, was carried out by adding suitable amounts of sulfate in the presence of increasing quantities of phosphate to achieve initial phosphate/sulfate molar ratios ranging from 0 to 1.0. The $\mathrm{pH}$ of each suspension was kept constant at $\mathrm{pH}$ 4.5 for $24 \mathrm{~h}$ by adding 0.1 or $0.01 \mathrm{~mol} \mathrm{~L}^{-1}$ $\mathrm{HCl}$ or $\mathrm{NaOH}$. The final suspensions $(20$ $\mathrm{mL}$ ) were centrifuged at $10,000 \mathrm{~g}$ for 20 $\mathrm{min}$, and filtered through a $0.22-\mu \mathrm{m}$ filter. Some experiments, (Andisol 5) were carried out by adding suitable amounts of sulfate in the presence of increasing quantities of phosphate to achieve initial phosphate/sulfate molar ratios ranging from 0 to 2.0. at different $\mathrm{pH}$ values $(2.5,3.5,4.5)$. Further experiments (Andisol 5) were carried out at
$\mathrm{pH} 4.5$ by adding sulfate $24 \mathrm{~h}$ before phosphate at initial phosphate/sulfate molar ratio ranging from 0 to 2 . Phosphate and sulfate were determined in the supernatant as described below.

\section{Kinetics of sorption of sulfate in the presence of phosphate and malate}

We also studied the kinetics of sorption of sulfate at $\mathrm{pH} 4.5$ alone and in the presence of phosphate or malate on Andisol 5.

At $300 \mathrm{mg}$ of soil samples suitable amounts of SO4 (150 mmol kg $\left.\mathrm{mm}^{-1}\right)$ were added in reaction flasks at initial $\mathrm{SO} 4 / \mathrm{PO}_{4}$ or $\mathrm{Mal}$ (malato) molar ratio of 2 . The suspensions were shaken from 0.08 to $168 \mathrm{~h}$. The final suspensions $(20 \mathrm{~mL})$ were centrifuged at $10.000 \mathrm{~g}$ for $20 \mathrm{~min}$, and filtered through a $0.22-\mu \mathrm{m}$ filter.

\section{Phosphate and sulfate determination}

Phosphate and sulfate were determined by ion chromatography, using a Dionex DX300 Ion Chromatograph (Dionex Co, Sunnyvale, CA), an IonPac AS4A column $(4.0 \mathrm{~mm})$, an eluent of $\mathrm{Na}_{2} \mathrm{CO}_{3}$ and $\mathrm{HNaCO} 3$ at a flow rate of $2 \mathrm{~mL} \mathrm{~min}^{-1}$, and a CD20 Conductivity Detector combined with autosuppression.

The standard concentrations were 0.2 to 2 mmol L $\mathrm{L}^{-1}$ for phosphate and sulfate. The amount of ligands adsorbed was determined by the difference between the initial and final concentrations. The data are the mean of two or three determinations. Coefficients of variation ranged from 1.5 to $5 \%$.

\section{RESULTS AND DISCUSSIONS}

Crystalline clay mineralogy was similar for all the studied samples, except for the $2 \mathrm{C}$ horizon of the pedon 2 (sample 5), which did not show crystalline minerals (Table 1). The soil samples showed content of allophane ranging from $16 \%$ (sample 2) to $42 \%$ (sample 5). 


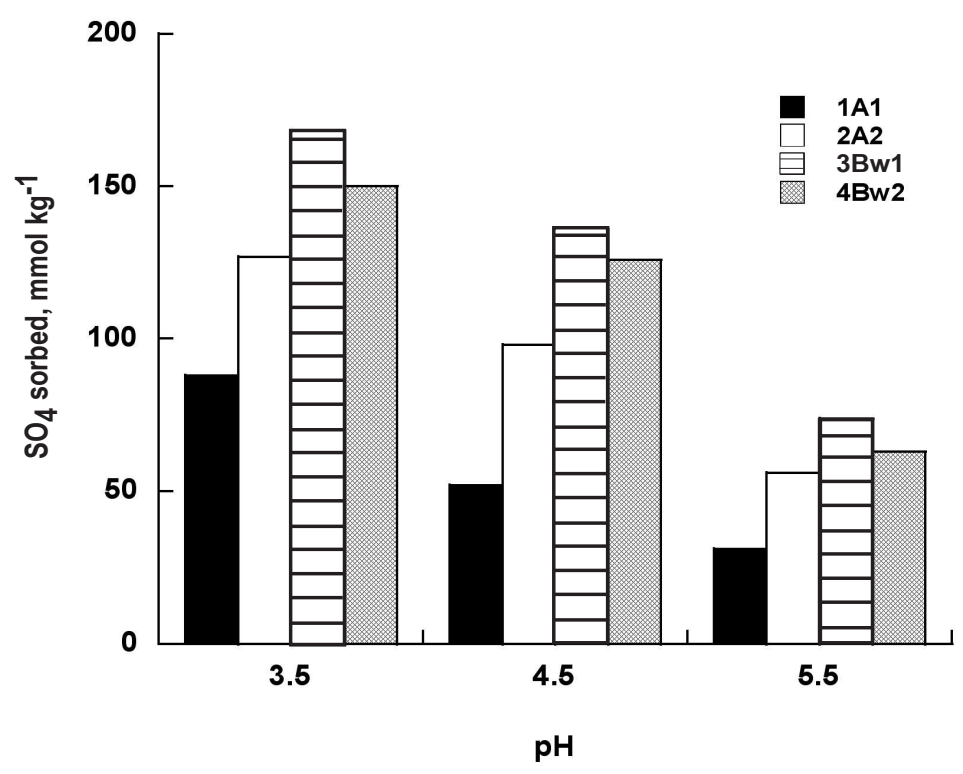

Figure 1: Sulfate $\left(\mathrm{SO}_{4}\right)$ sorption $\left(\mathrm{mmol} \mathrm{kg}^{-1}\right)$ at $\mathrm{pH} 3.5,4.5$ and 5.5 , on selected soil samples of the horizons A1, 2A2, 3Bw1 and 4Bw2 (samples 1-4) of an Eutric Fulvudand (Pedon 1). Sulfate added was $466 \mathrm{mmol} \mathrm{kg}^{-1}$.

Figura 1: Adsorción de sulfato $\left(\mathrm{mmol} \mathrm{kg}^{-1}\right)$ a pH 3.5, 4.5 y 5.5 en muestras de suelo seleccionadas de los horizontes A1, 2A2, 3Bw1 y 4Bw2 (muestras 1-4) de un Eutric Fulvudand (Pedon 1). La cantidad de sulfato adicionado fue $466 \mathrm{mmol} \mathrm{\textrm {kg } ^ { - 1 }}$.

\section{Sorption of sulfate on Andisols}

Figure 1 shows the sorption of sulfate onto soil samples of Pedon 1 (samples 1-4) at three different $\mathrm{pH}$ values $(3.5,4.5$, and 5.5).

If we consider the first 3 horizons (A1, $2 \mathrm{~A} 2$ and $3 \mathrm{Bw} 1$ ) of the pedon 1 , the increase in sorption of sulfate appears evident along the profile (Figure 1). This behaviour was attributable to a decrease in C content (184, 74 , and $37 \mathrm{~g} \mathrm{~kg}-1$, respectively in horizons $\mathrm{A} 1,2 \mathrm{~A} 2$ and $3 \mathrm{Bw} 1$; Table 1). It is well know that organic samples (humic and fulvic acids as well as low molecular mass organic ligands), sorbed on variable charge minerals or present in organo-mineral complexes prevent sulfate sorption competing for sorption sites (Violante et al., 2002). The increase of sulfate sorption in the 3Bw1 sample must be also attributed to a greater percentage of allophanic materials (27\% vs $16-17 \%$ in the first two horizons).

Sorption experiments were also carried out at different $\mathrm{pH}$ values $(\mathrm{pH}$ ranging from 4.0 to 8.0 ) on the samples 1 and 5 characterized by different chemical, physicochemical and mineralogical properties (Tables 1-2) (Figure 2). On these soil samples sulfate sorption drastically decreased by increasing the $\mathrm{pH}$ from 4.0 to 7.0 , precisely by $80 \%$ for sample 5 to $100 \%$ for sample 1. Hingston et al. (1972) also showed that sulfate sorption on goethite decreased with an increase in $\mathrm{pH}$ up to 8.0, beyond which no sorption occurred. The 


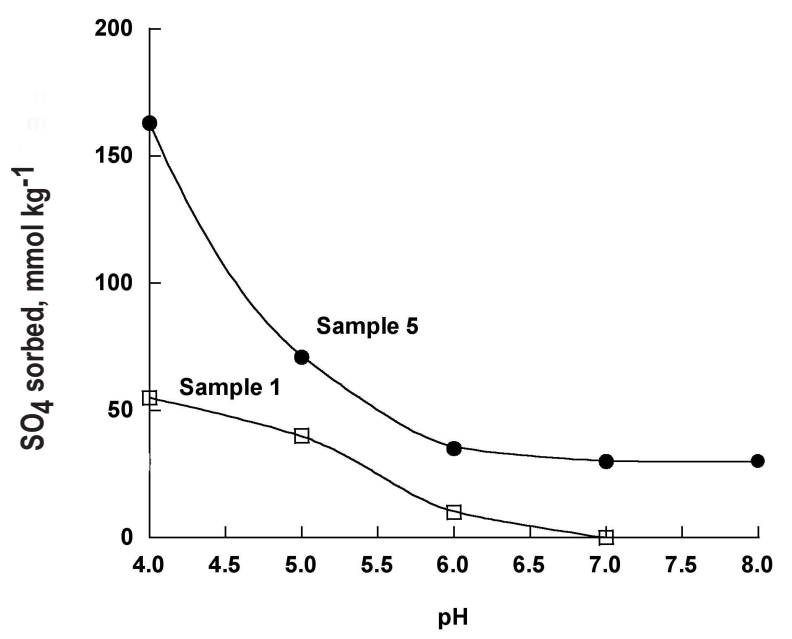

Figure 2: Influence of $\mathrm{pH}$ on the sulfate ( $\left.\mathrm{SO}_{4}\right)$ sorption on andisols 1 and 5. Sulfate added was $466 \mathrm{mmol} \mathrm{kg}^{-1}$.

Figura 2: Influencia del pH sobre la adsorción de sulfato ( $\mathrm{SO} 4)$ sobre los Andisoles 1 y 5 . La cantidad de sulfato adicionado fue $466 \mathrm{mmol} \mathrm{kg}^{-1}$.

negligible sorption of sulfate on variable charge minerals and soils at $\mathrm{pH}>7.0$ has been widely documented (Couto et al., 1979; Pasricha and Fox, 1993; Violante et al., 1996; Liu et al., 1999).

\section{Sorption of sulfate in the presence of phosphate}

Experiments were carried out on the sorption of sulfate in the presence of phosphate at pH 4.5 on selected soil samples (samples 1-4). The anions were added as a mixture at initial phosphate/sulfate molar ratios (R) ranging from 0 to 1 and sulfate was added at its maximum surface coverage on each sample (Figure 3). Sulfate sorption was strongly inhibited by the presence of phosphate even at $R<1$. In fact, at $R=$ 0.2 we observed a decrease of sulfate sorption of about $10 \%$ for sample 1 and about $40-45 \%$ for samples 2-4 (Figure 3).

The decrease of sulfate sorption on soil samples cannot be attributed only to competition in sorption between phosphate and sulfate, because the sulfate sorption decrease was much greater than the amounts of phosphate added and sorbed (data not shown). A possible explanation of these findings is that phosphate sorption on soil samples decreased their surface charge and point of zero charge (PZC), preventing the fixation of sulfate ions on more negative surfaces (Parfitt, 1990; Violante and Pigna, 2002). According to Barrow (1992) the competition of anions for sorption sites of variable charge minerals was largely through changes in the electric potential of the surface. Recently, Violante and Pigna (2002) demonstrated that competition for sorption sites is a very important mechanisms, but certainly reduction in the surface charge of the sorbents is also very significative, particularly when a ligand (phosphate in our study) is sorbed more strongly than the other anion (sulfate in our study). 


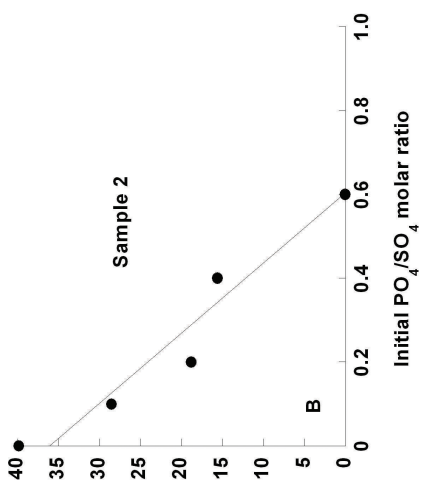

6y roum 'pəquos tos

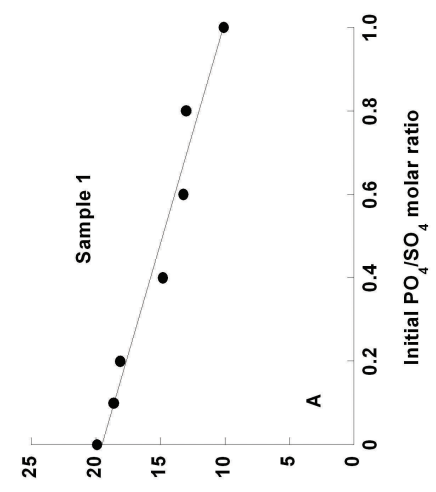

6y joum 'pequos os

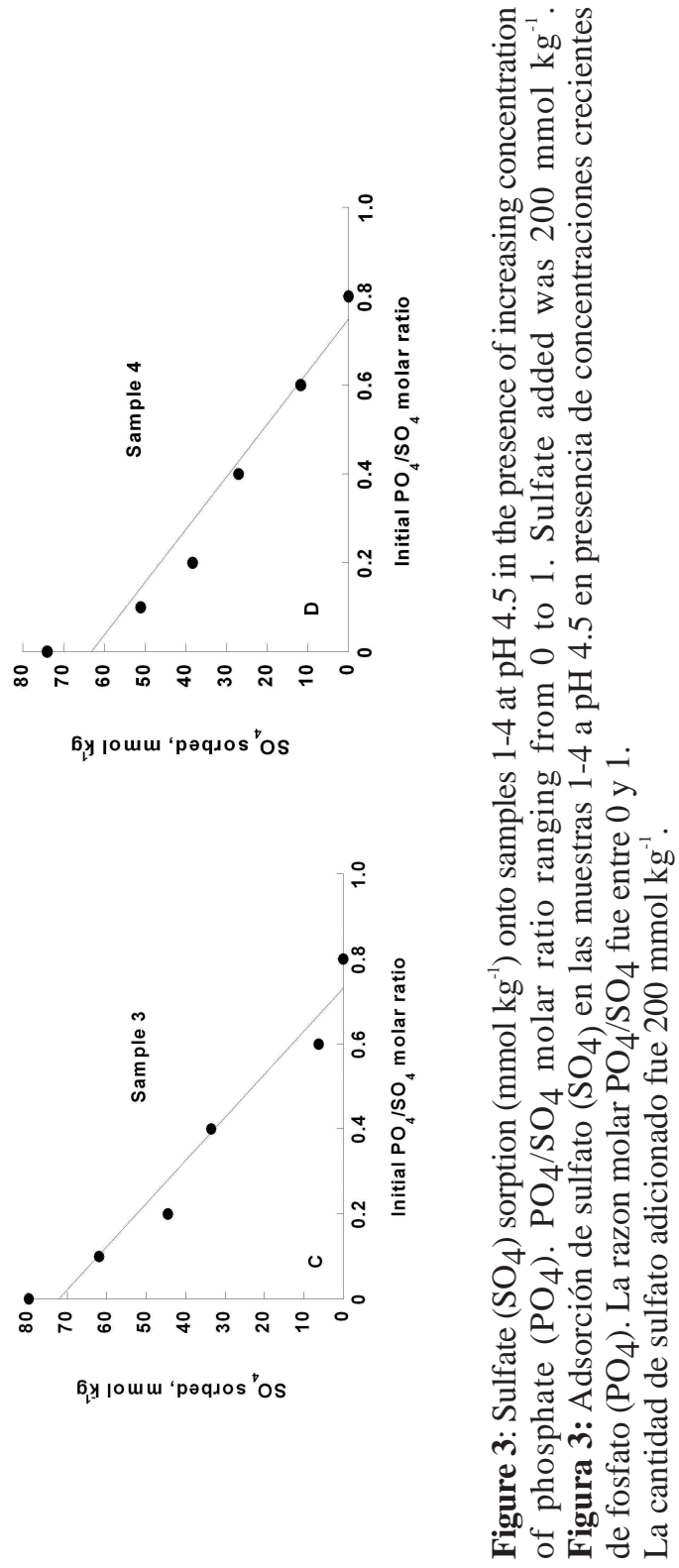




\section{Effect of pH on the competitive sorption of sulfate and phosphate}

Experiments on sorption of sulfate in the presence of increasing amounts of phosphate ( $\mathrm{R}$ ranging from 0 to 2 ) were carried out at different acid $\mathrm{pH}$ values ( $\mathrm{pH} 2.5,3.5$ and 4.5) on Andisol 5 (Figure 4). It has been found that the lower the $\mathrm{pH}$ the greater the capacity of sulfate to compete with phosphate. For example, at $\mathrm{R}=1$, phosphate inhibited sulfate sorption of $30 \%$ at $\mathrm{pH} 2.5$ versus 40 and $94 \%$ at $\mathrm{pH} 3.5$ and 4.5 , respectively. A possible explanation of these findings is that sulfate forms inner-sphere complexes particularly at low $\mathrm{pH}$ values (Turner and Kramer, 1991; Sparks, 1999). Peak et al. (2001) found that sulfate formed a second bidentate binuclear surface complex on goethite at pH 3.5. Evidently, particularly at low $\mathrm{pH}$ values sulfate ions form strong complexes on some surface sites from which they cannot be easily desorbed in spite that phosphate and some organic ligands are more able to remove sulfate at acidic than neutral or alkaline environment (Jara et al., 2006).

Liu et al. (1999) found that at $\mathrm{pH} 4.5$ oxalate up to oxalate/sulfate molar ratio of 2 (r) strongly inhibited the sorption of sulfate, but at $r>2$ the sorption of sulfate remained practically constant. These authors concluded that $25-30 \%$ of sulfate was sorbed so strongly onto goethite that even large amounts of oxalate $(r=3.33)$ were not able to replace it.

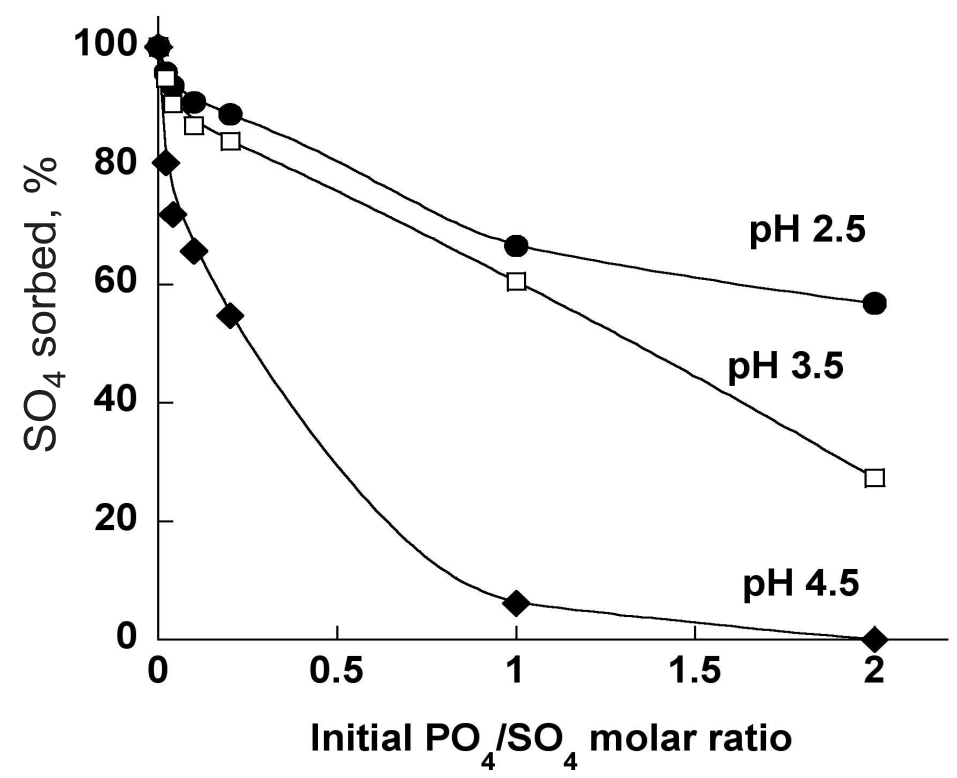

Figure 4: Sulfate (SO4) sorption (\%) on sample 5 at pH 2.5, 3.5 and 4.5, in the presence of increasing concentration of phosphate (PO4). The \% SO 4 sorbed as referred to sulfate

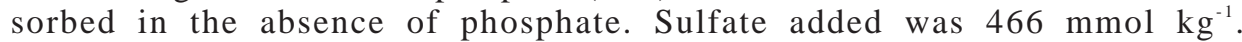
Figura 4: Adsorción de sulfato ( $\mathrm{SO}_{4}$ ) sobre la muestra 5 a pH 2.5, 3.5 y 4.5, en presencia de concentraciones crecientes de fosfato (PO4). $\mathrm{El} \% \mathrm{SO} 4$ es referido al sulfato adsorbido en ausencia de fosfato. La cantidad de sulfato adicionado fue $466 \mathrm{mmol} \mathrm{kg}{ }^{-1}$. 


\section{Effect of sequence addition}

When sulfate was added $24 \mathrm{~h}$ before phosphate ( $\mathrm{SO} 4$ before $\mathrm{PO} 4$ system) (Figure 5) greater quantities of sulfate were sorbed on Andisol 5 with respect to the quantities fixed when phosphate and sulfate were added as a mixture (SO4 + $\mathrm{PO} 4$ systems). At $\mathrm{R}=0.1,0.2$, and 1 the sulfate sorption decreased, respectively, of 10,22 , and $70 \%$ in $\mathrm{SO} 4$ before $\mathrm{PO} 4$ system versus 34,45 , and $94 \%$ in the $\mathrm{PO}_{4}+\mathrm{SO}_{4}$ systems.

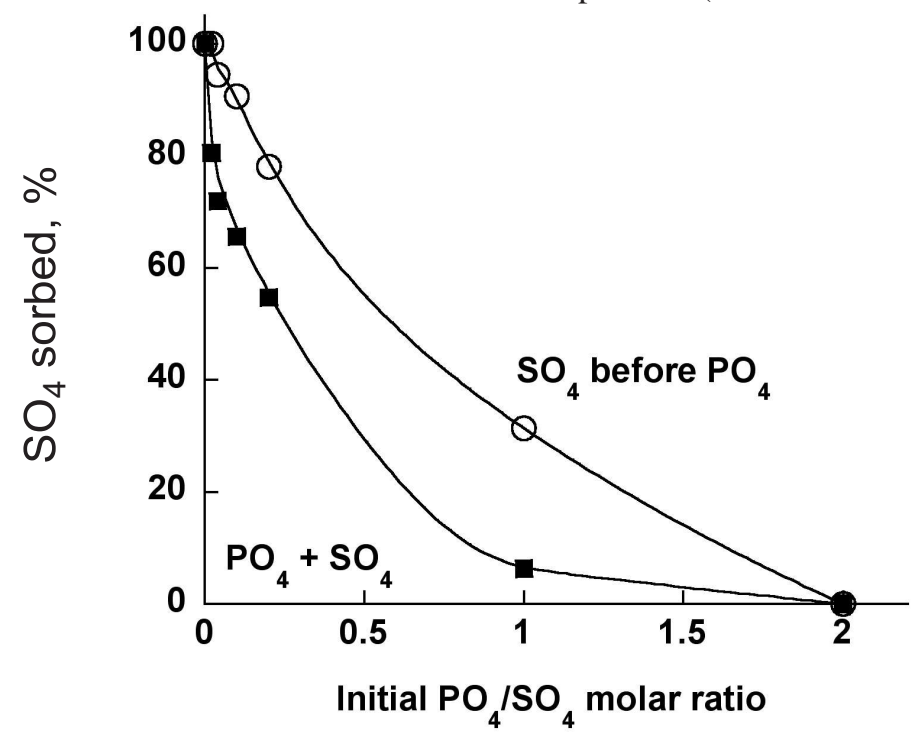

Figure 5: Sulfate ( $\mathrm{SO} 4)$ sorption on sample 5, at $\mathrm{pH} 4.5$, in the presence of increasing concentration of phosphate (PO4). The anions were added together ( $\mathrm{PO} 4+\mathrm{SO} 4$ system) or by adding sulfate 24 hours before phosphate ( $\mathrm{SO} 4$ before $\mathrm{PO} 4$ system). Sulfate added was $466 \mathrm{mmol} \mathrm{kg}^{-1}$.

Figura 5: Adsorción de sulfato sobre la muestra 5 a pH 4.5 en presencia de concentraciones crecientes de fosfato (PO4). Los aniones fueron adicionados juntos (sistema $\mathrm{SO} 4+\mathrm{PO} 4$ ) o por adición de sulfato 24 horas antes que fosfato (sistema $\mathrm{SO} 4$ antes que PO4). La cantidad de sulfato adicionado fue $466 \mathrm{mmol} \mathrm{kg}^{-1}$.

\section{Kinetics of sorption of sulfate in the presence of phosphate and malate}

We also studied the kinetics sorption of sulfate on Andisol 5 at $\mathrm{pH} 4.5$, when added alone $\left(150 \mathrm{mmol} \mathrm{kg}^{-1}\right)$ or in the presence of phosphate or malate $\left(\mathrm{SO}_{4} / \mathrm{PO} 4\right.$ or $\mathrm{Mal}$ molar ratio of 2). The kinetics was evaluated using first order, Parabolic diffusion, and Elovich kinetics models (data not shown).
Similar results were found studying the competitive sorption of sulfate and phosphate on to a $\mathrm{Al}-\mathrm{Si}$ and $\mathrm{Fe}-\mathrm{Al}-\mathrm{Si}$ allophane (Pigna et al, 2003). Different processes may concur in the sorption reactions of different ligands on soil components, as i) the kind of surface complexes formed by the anions when added as a mixture in different amounts, ii) the change in the surface charge after anions adsorption and iii) the effect of time on competition (Violante and Pigna, 2002). 
presence of low amounts of $\mathrm{PO} 4$ or Mal strongly prevented $\mathrm{SO}_{4}$ sorption even though many sites were still available for $\mathrm{SO} 4$ sorption. In the presence of $\mathrm{PO} 4$ or Mal the maximum amount of $\mathrm{SO} 4$ sorbed was reached after 24-48 h, no further increase was observed even after $48 \mathrm{~h}$ (Figure 6).
Compared to the SO4-alone, about $70 \%$ of $\mathrm{SO}_{4}$ was sorbed in the presence of $\mathrm{PO}_{4}$, and $86 \%$ in the presence of Mal after 168 h. However, after $360 \mathrm{~h}$ of reaction the amounts of $\mathrm{SO} 4$ sorbed in the presence of PO4 or Mal did not increase further (data not shown).

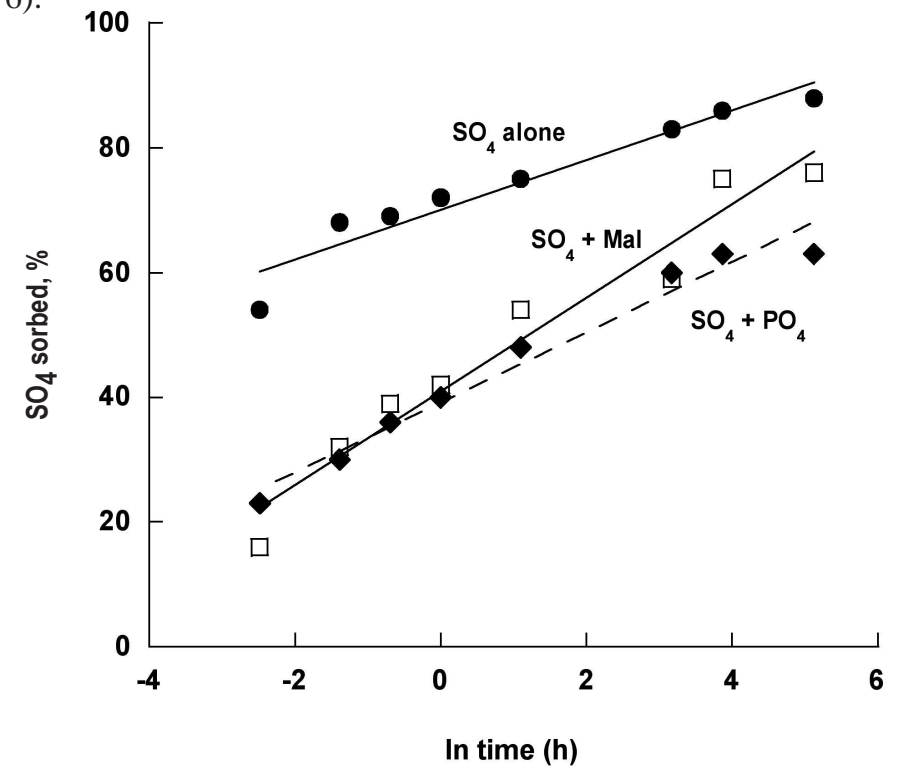

Figure 6: Effect of time on the kinetic sorption of sulfate (SO4) on andisol 5 at $\mathrm{pH} 4.0$ when added alone $\left(150 \mathrm{mmol} \mathrm{kg}^{-1}\right)$ and in the presence of phosphate (PO4) or malate (Mal). Initial SO4/PO4 or Mal molar ratio of 2. The kinetics were fitted using Elovich model.

Figura 6: Efecto de tiempo sobre la cinética de adsorción de sulfato (SO4) sobre Andisol 5 a pH 4.0 cuando fue adicionado solo $\left(150 \mathrm{mmol} \mathrm{kg}^{-1}\right)$ y en presencia de fosfato (PO4) o malato (Mal). Razon molar inicial SO4/PO4 o Mal de 2. Las cinéticas fueron ajustadas usando el modelo de Elovich.

\section{CONCLUSIONS}

In this study on the sorption of sulfate on Andisols we have found that: i) sulfate sorption was strongly prevented by phosphate even at phosphate/sulfate molar ratios $<<1$; ii) $\mathrm{pH}$ strongly influenced the competition in sorption between phosphate and sulfate; at very low $\mathrm{pH}$ values $(<4.5)$ sulfate anions competed with phosphate probably forming inner-sphere complexes; iii) when sulfate was added before phosphate (SO4 before $\mathrm{PO} 4$ system) more sulfate was sorbed than when sulfate was added with phosphate or after phosphate; iv) in the presence of phosphate or malate the kinetics of sulfate sorption on Andisol was retarded (phosphate $>$ malate).

\section{ACKNOWLEDGEMENTS}

This study was supported by the Italian Research Program of National Interest (PRIN), year 2004. DISSPAPA Number 141 


\section{REFERENCES}

BARROW, N.J. 1992. The effect of time on the competition between anions for sorption. Soil Sci J. 43: 424-428.

COUTO, W., LATHWELL, D.J., BOULDEN, D.R. 1979. Sulfate sorption by two Oxisols and an Alfisol of the tropics. Soil Sci. 127: 108-116.

GUNJIGAKE, N., WADA, K. 1980. Effects of phosphorus concentration and $\mathrm{pH}$ on phosphate retention by active aluminium and iron of Andosoils. Soil Sci. 132: 347-352.

HINGSTON, R.J., POSNER, A.M., QUIRK, J.P. 1972. Anion adsorption by goethite and gibbsite. The roleof the proton in determining adsorption envelopes. J. Soil Sci. 23: 177-193.

HUANG, P.M., VIOLANTE, A. 1986. Influence of organic acids on crystallization and surface properties of precipitation products of aluminum. In Interactions of Soil Minerals with Natural Organics and Microbes; Huang, P.M., Schnitzer, M., Eds.; SSSA Spec. Publ. 17. SSSA, Madison, WI, 159-221.

ITALIA MINISTRY AGRICULTURAL and FORESTRY POLICY. 2000. Metodi di Analisi Chimica del Suolo. Collana di Metodi Analitici per l'Agricoltura, Franco Angeli Editore.

JARA, A., VIOLANTE, A., PIGNA, M. MORA, M. 2006. Mutual interaction of sulfate, oxalate, citrate and phosphate on synthetic and natural allophanes. Soil Sci. Soc. Am. J. 70: 337-346.

LIU, F., HE, J., COLOMBO, C., VIOLANTE, A. 1999. Competitive adsorption of sulfate and oxalate on goethite in the absence or presence of phosphate. Soil Sci. 164: 180-189.

MORA, M.L., CANALES, J. 1995. Interactions of humic substances with allophanic compounds. Commun. Soil Sci. Plant Anal. 26: 2805-2817.
MORA, M.L., SHENE, C., VIOLANTE, A., DEMANET, R., BOLAN, N.S. 2005. The effect of organic matter and soil chemical properties on sulfate sorption in Chilean volcanic soil. In Soil abiotic \& biotic interaction and the impact on the ecosystem \& human welfare, Huang, P.M., Violante, A., Bollag, J.-M., Vityakon, P. Eds. Science Publishers (Enfield, NH USA), pp.223-244.

PARFITT, R.L. 1990. Allophane in New Zeland - A review. Aust. J. Soil Res., 28: 343-360.

PASRICHA, N.S., FOX, R.I. 1993. Plant nutrient sulfur in the tropics and subtropics. Adv. Agron. 50: 209-269.

PEAK, D., ELZINGA, E.J., SPARKS, D.L. 2001. Understanding sulfate adsorption mechanisms on iron (III) oxides and hydroxides: Results from ATR-FTIR Spectroscopy. In Heavy metals release in soil; Selim, H.L., Sparks, D.L. Eds. Lewis Pub. Boca Raton, 167-190.

PIGNA, M., DE LA LUZ MORA, M., VIOLANTE, A. 2003. Adsorbimento competitivo di ioni fosfato e solfato su andisuoli e allofani di Sintesi. Atti del XX Convegno Nazionale SICA (Padova), pp 131-138.

SPARKS, D.L. 1999. Kinetics and mechanisms of chemical reactions at the soil mineral/water interface. In Soil Physical Chemistry; Sparks, D.L., Ed., CRC Press, Boca Raton, FL, 1999, 135-191.

TURNER, L.J., KRAMER, J.R. 1991. Sulfate ion binding on goethite and ematite. Soil Sci. 152: 226-230.

VACCA, A., ADAMO, P., PIGNA, M., VIOLANTE, P. 2003. Genesis of Tephra-derived Soils from the Roccamonfina Volcano, CentralSouthern Italy. Soil Sci. Soc. Am. J., 67, 198-207. 
VIOLANTE, A., RAO, M.A., DE CHIARA, A., GIANFREDA, L. 1996. Sorption of phosphate and oxalate by a synthetic aluminium hydroxysulphate complex. Eur. J. Soil Sci.. 47: 241-247.

ViOlAnTE, A., PIGNA, M. 2002. Competitive sorption of arsenate and phosphate on different clay minerals and soils. Soil Sci. Soc. Am. J. 66: 1788-1796.

VIOLANTE, A., KRISHNAMURTI, G.S.R., HUANG, P.M. 2002. Impact of organic substances on the formation and transformation of metal oxides In Soil Environments. In Interactions Between Soil Particles and Microorganisms and the Impact on Terrestrial Environment; Huang, P.M., Bollag, J.M., Senesi, N., Eds.; John Wiley \& Sons Ltd, 133-188.
WADA, K. 1989. Allophane and imogolite. In Minerals in Soil Environments, 2nd; Dixon, J.B. Weed, S.B., Eds.; SSSA Book Ser. 1. SSSA, Madison, WI, 1051-1087.

WALKLEY, A., BLACK, I..A. 1934. An examination of the degtjareff method for determining soil organic matter and a proposed modification of the cromic acid titration method. Soil Sci. 37: 29-38.

ZHANG, P.C., SPARKS, D.L. 1990. Kinetics and mechanisms of sulfate adsorption/desorption on goethite using pressure-jump relaxation. Soil Sci. Soc. Am. J. 54: 1266-1273. 